\title{
ANALISIS NILAI TAMBAH BROKOLI KEMASAN CV. YAN'S FRUITS AND VEGETABLE DI KECAMATAN LEMBANG BANDUNG BARAT
}

\author{
Clara Yolandika*1, Rita Nurmalina ${ }^{2}$, Suharno $^{3}$ \\ ${ }^{1,2,3}$ Magister Sains Agribisnis, Intitut Pertanian Bogor \\ e-mail: *11 clarayolandika@gmail.com
}

\begin{abstract}
This study aimed to analyze broccoli added value in CV. Yan's Fruits and Vegetable. The study was conducted at CV. Yan's Fruits and Vegetable from July to August 2016. This study used primary and secondary data. The research sample was taken purposively consisting of 30 farmers of $C V$. Yan's Fruits and Vegetable partners. The method used to analyse supply chain condition was Hayami Method to analyze broccoli added value in CV. Yan's Fruits and Vegetable. The results showed that the marketing condition of broccoli in Cibodas Village is already good. They already have a good integration among members of the supply chain. Integrated quality and optimization of the supply chain have been the targets of any relevant actors in the broccoli supply chain so it can create added value for broccoli. From the added value calculation of packaged broccoli, it can be concluded that it has added value of 36.92 percent.
\end{abstract}

Keywords: Broccoli, packing, Value-Added

\section{Pendahuluan}

Brokoli merupakan salah satu komoditas hortikultura jenis sayuran berdaun hijau tua kelompok Brassica, keluarga dari tanaman jenis kubis-kubisan. Sayuran ini berasal di Italia, di mana nama brokoli berasal dari Bahasa Italia broccolo, yang berarti cabang'dan pertama kali dibudidayakan di abad ke-17. Brokoli adalah salah satu sayuran yang paling populer di seluruh dunia yang digunakan dalam berbagai hidangan dan masakan, baik secara mentah ataupun dimasak. Brokoli telah lama dijuluki "The King of Vegetable" karena memiliki manfaat kesehatan yang luar biasa. Nilai gizi dari brokoli dapat dianggap sebagai pembangkit tenaga zat besi, protein, kalsium, kromium, karbohidrat, vitamin A dan vitamin C. Brokoli juga mengandung phytochemical dan antioksidan, yang melawan berbagai penyakit dan infeksi (Zulkarnain, 2009).

Menurut Suwarto (2010), brokoli memiliki berbagai keunggulan dibandingkan dengan sayuran lainnya. Brokoli mengandung dua senyawa fitokemikal yang berfungsi untuk meningkatkan enzim dan dapat menghancurkan karsinogenik yang merupakan penyebab terjadinya penyakit kanker. Selain itu, pada brokoli juga terdapat kandungan chromium yang berguna untuk mengatur tingkat gula darah dalam tubuh. Brokoli juga mengandung serat dan juga campuran Omega-3, beta karotan, dan juga beberapa vitamin lainnya yang berfungsi untuk menurunkan kolesterol dan juga mengatur tekanan darah. Hal ini menyebabkan brokoli mulai banyak diminati oleh masyarakat Indonesia.

Perubahan pola hidup pada umumnya terjadi pada masyarakat yang hidup di kota besar dengan tingkat ekonomi menengah dan menengah ke atas. Salah satu perubahan yang cukup signifikan adalah mulai beralihnya pola konsumsi masyarakat dari mengkonsumsi sayuran yang berkadar gizi rendah menjadi sayuran berkualitas dan berkadar gizi tinggi, terutama brokoli. 
Namun, terdapat beberapa kendala dalam usaha memenuhi permintaan sayuran yang berkualitas tersebut, diantaranya kurangnya pengetahuan petani mengenai sistem penanaman yang tepat, sehingga dapat menghasilkan produk dengan kualitas yang baik dan juga memiliki kuantitas yang besar, serta berkelanjutan.

Menurut Direktorat Jenderal Hortikultura (2014), permintaan brokoli di Indonesia cenderung mengalami peningkatan. Hal ini menunjukkan brokoli memiliki potensi untuk dikembangkan dan dapat membantu memajukan pertanian Indonesia karena permintaan yang tinggi dari pasar dalam negeri. Namun, untuk memenuhi permintaan dari luar negeri dibutuhkan volume produksi dan produktivitas yang tinggi dan berkelanjutan agar tidak kalah dengan sayuran dari negara pesaing.

Data konsumsi brokoli per kapita dari Susenas (2015) menunjukkan bahwa konsumsi brokoli mengalami peningkatan setiap tahun. Peningkatan konsumsi menunjukkan terjadinya peningkatan permintaan brokoli dalam negeri, terutama di kota-kota besar, sehingga diperlukan perlakuan khusus mulai dari subsistem hulu hingga hilir agar kesegaran dan kesehatan produk tetap terjaga ketika sampai di tangan konsumen akhir. Untuk meningkatkan produksi, produktivitas, mutu, dan daya saing secara optimal, diperlukan penanganan yang efektif dan efisien antar aspek produksi dan distribusi. Salah satu kegiatan prioritas yang telah disusun oleh Direktorat Jenderal Hortikultura yang terdapat dalam "Enam Pilar Kegiatan Pengembangan Hortikultura Tahun 2012" untuk memperbaiki pemasaran produk hortikultura adalah dengan mengaplikasikan manajemen rantai pasok atau supply chain management.

Manajemen rantai pasok merupakan bentuk manajemen pemasaran yang mengintegrasikan seluruh subsistem dan lembaga yang terlibat untuk menghasilkan produk murah, berkualitas, sampai tepat waktu, dan bervariasi yang memiliki nilai tambah (Pujawan, 2005). Hal penting dalam manajemen rantai pasok adalah menjaga kelancaran aliran nilai agar dapat memenuhi keinginan konsumen akhir secara berkelanjutan. Para pelaku rantai pasok perlu menjaga hubungan baik satu sama lain untuk mencapai tujuan rantai pasok dengan cara melakukan peningkatan efisiensi rantai pasok secara terus menerus (continuous improvement). Perbaikan kualitas, harga, kuantitas produk, serta pengiriman tepat waktu akan memberikan kepuasan kepada konsumen dan meningkatkan pendapatan bagi pelaku rantai pasok. Tujuan dari penelitian ini yaitu: menganalisis nilai tambah dari produk brokoli kemasan pada CV. Yan's Fruits and Vegetable.

\section{Metode}

Penelitian ini akan dilaksanakan di CV. Yan's Fruits and Vegetable di Kecamatan Lembang, Kabupaten Bandung Barat. Pemilihan lokasi penelitian dilakukan secara sengaja (purposive sampling) berdasarkan pertimbangan kondisi wilayah penelitian yang merupakan salah satu sentra sayuran di Jawa Barat dan keadaan alamnya cocok untuk budidaya brokoli, adanya kerjasama mitra dengan beberapa petani mitra brokoli dan menjadi ritel utama di wilayah Jakarta sekitarnya, serta terdapat permasalahan gap antara jumlah permintaan pasar dengan jumlah sayuran oleh petani mitra kepada perusahaan. Penelitian ini dilaksanakan mulai dari bulan Juli hingga Agustus 2016.

Jenis data yang digunakan dalam penelitian ini adalah data primer dan data sekunder, baik yang bersifat kualitatif maupun kuantitatif. Data primer diperoleh dari observasi atau pengamatan langsung di lokasi penelitian dan wawancara mendalam dengan pelaku rantai pasok. Responden pada penelitian ini adalah petani mitra yang memproduksi brokoli dan CV. Yan's Fruits and Vegetable sebanyak 30 orang petani mitra. Data sekunder diperoleh melalui literatur, data-data relevan yang dikeluarkan oleh lembaga-lembaga pemerintah atau instansi terkait, artikel, jurnal, dan penelitian-penelitian terdahulu sebagai bahan perbandingan.

Penelitian ini membutuhkan pendekatan metode kualitatif dan kuantitatif untuk mengolah data primer dan sekunder. Untuk menganalisis rantai pasok diperlukan data kualitatif dan kuantitatif. Model rantai pasok yang terjadi di CV. Yan's Fruits and Vegetable dibahas secara 
deskriptif dengan menggunakan metode pengembangan mengikuti kerangka proses FSCN dari Lambert dan Cooper (2000) yang dimodifikasi oleh Vorst (2006). Kerangka FSCN terdiri dari saaran rantai pasok, struktur rantai pasok, manajemen rantai pasok, sumber daya rantai pasok, dan proses bisnis rantai pasok. Etelah itu dilakukan analisis nilai tambah dengan Metode Hayami. Prosedur perhitungan nilai tambah pengolahan dengan Metode Hayami dapat dilihat pada Tabel 1.

Tabel 1 Prosedur perhitungan nilai tambah menggunakan Metode Hayami

\begin{tabular}{|c|c|c|}
\hline No & Variabel & Nilai \\
\hline \multicolumn{3}{|c|}{ Output, Input, dan Harga } \\
\hline 1. & Output $(\mathrm{kg})$ & (1) \\
\hline 2. & Bahan Baku (kg) & (2) \\
\hline 3. & Tenaga Kerja Langsung (HOK) & (3) \\
\hline 4. & Faktor Konversi & $(4)=(1) /(2)$ \\
\hline 5. & Koefisien Tenaga Kerja Langsung (HOK/kg) & $(5)=(3) /(2)$ \\
\hline 6. & Harga Output (Rp/kg) & (6) \\
\hline 7. & Upah Tenaga Kerja Langsung (Rp/HOK) & (7) \\
\hline \multicolumn{3}{|c|}{ Penerimaan dan Keuntungan } \\
\hline 8. & Harga Bahan Baku (Rp/kg) & (8) \\
\hline 9. & Harga Input lain (Rp/kg) & (9) \\
\hline 10. & Nilai Output $(\mathrm{Rp} / \mathrm{kg})$ & $(10)=(4) \times(6)$ \\
\hline \multirow[t]{2}{*}{11.} & a. Nilai Tambah (Rp/kg) & $(11 a)=(10)-(8)-(9)$ \\
\hline & b. Rasio Nilai Tambah (\%) & $(11 b)=(11 a) /(10) \times 100$ \\
\hline \multirow[t]{2}{*}{12.} & a. Pendapatan tenaga kerja Langsung $(\mathrm{Rp} / \mathrm{kg})$ & $(12 a)=(5) \times(7)$ \\
\hline & b. Pangsa tenaga kerja langsung (\%) & $(12 b)=(12 a) /(11 a) \times 100$ \\
\hline \multirow[t]{2}{*}{13.} & a. Keuntungan (Rp/kg) & $(13 a)=(11 a)-(12 a)$ \\
\hline & b. Tingkat Keuntungan (\%) & $(13 b)=(13 a) /(10) \times 100$ \\
\hline \multicolumn{3}{|c|}{ Balas Jasa Pemilik Faktor Produksi } \\
\hline & Marjin (Rp/kg) & $(14)=(10)-(8)$ \\
\hline & a. Pendapatan tenaga kerja langsung (\%) & $(14 a)=(12 a) /(14) \times 100$ \\
\hline & b. Sumbangan input lain (\%) & $(14 b)=(9) /(14) \times 100$ \\
\hline & c. Keuntungan perusahaan (\%) & $(14 c)=(13 a) /(14) \times 100$ \\
\hline
\end{tabular}

\section{Hasil dan Pembahasan}

\section{Gambaran Umum Lokasi Penelitian}

Rantai pasok brokoli di Kabupaten Bandung mengalirkan brokoli berkualitas baik yang sudah dalam bentuk kemasan. Rantai pasok ini terdiri dari petani yang bermitra, CV. Yan's Fruits and Vegetable, retailer, dan konsumen akhir. Brokoli yang telah dipanen oleh petani akan dialirkan ke CV. Yan's Fruits and Vegetable, kemudian ada yang langsung dialirkan ke pasar tradisional apabila brokoli tersebut memiliki kualitas yang buruk. Akan tetapi, pada penelitian ini, akan difokuskan pada brokoli dengan kualitas terbaik yang disalurkan petani ke CV. Yan's Fruits and Vegetable. Dari CV. Yan's Fruits and Vegetable, brokoli akan dikemas kemudian dialirkan ke ritel yang merupakan supermarket besar yang ada di wilayah Jabodetabek (Jakarta, Bogor, Depok Tangerang, dan Bekasi). 
Terdapat 30 orang petani brokoli yang bermitra dengan CV. Yan's Fruits and Vegetable, dimana dari 30 petani, 5 petani merupakan pemasok utama brokoli ke CV. Yan's Fruits and Vegetable. Seluruh petani mitra tersebut bergabung dengan Kelompok Usahatani Mekar Tani Jaya, dimana disanalah petani memperoleh pengetahuan tentang budidaya brokoli yang berkualitas. Lahan yang digunakan petani untuk budidaya brokoli berlokasi di Kecamatan Lembang, tetapi pada daerah yang berbeda-beda. Petani mitra juga memiliki karakteristik yang berbeda-beda.

Dari seluruh petani mitra yang dijadikan sebagai responden, sebagian besar berjenis kelamin laki-laki. Hanya terdapat tiga petani mitra yang berjenis kelamin perempuan. Rentang umur petani mitra yaitu 20 hingga 65 tahun. Sebagian besar petani mitra hanya memperoleh pendidikan pada tingkat Sekolah Dasar (SD) yaitu 53.33 persen. Luas areal rata-rata usahatani brokoli yang diusahakan petani mitra adalah rata-rata 0,32 hektar.

\section{Kondisi Rantai Pasok Brokoli}

Sasaran pasar produk brokoli kemasan CV. Yan's Fruits and Vegetable masih ditujukan untuk pasar domestik ritel. Hal ini dikarenakan petani mitra penghasil brokoli masih sedikit dan ada petani mitra yang belum memasok dengan kuantitas yang besar dengan kualitas terbaik. Selain itu, untuk memasarkan ke supermarket dan luar negeri (ekspor), dibutuhkan persyaratan khusus yang belum dapat dipenuhi, seperti produk harus tahan lama dan tetap segar. Untuk memasarkan ke luar negeri, produk sayuran membutuhkan perlakuan khusus pada pengemasan dan selama proses distribusi agar kesegarannya tetap terjaga. Hal ini disebabkan pemasaran ke pasar ekspor akan melalui jarak yang relatif jauh dan waktu yang relatif lama.

Sasaran pengembangan yang ingin dicapai produk brokoli kemasan pada CV. Yan's Fruits and Vegetable adalah penguatan rantai pasok dengan cara pelaksanaan kemitraan yang berkesinambungan. Kerjasama kemitraan ataupun koordinasi lainnya yang melibatkan petani mitra, CV. Yan's Fruits and Vegetable, pihak ritel serta beberapa institusi pendukung diarahkan kepada perbaikan dan peningkatan kualitas, kuantitas, dan kontinuitas produk, dan pengembangan serta perbaikan infrastruktur (Yolandika, 2016).

Dalam sebuah rantai pasok suatu komoditas terdapat dua jenis anggota yaitu anggota primer dan anggota sekunder. Anggota primer adalah pihak-pihak yang terlibat secara langsung dalam kegiatan bisnis rantai pasok. Anggota primer pada rantai pasok komoditas brokoli adalah petani brokoli mitra sebagai pemasok, perusahaan atau CV. Yan's Fruits and Vegetable sebagai pengolah (pengemasan), dan ritel (supermarket) sebagai konsumen. Koordinasi antar anggota didasari oleh kesadaran bahwa kuatnya rantai pasok tergantung pada kekuatan seluruh elemen yang ada di dalamnya. Anggota sekunder adalah pihak yang memperlancar kegiatan rantai pasok dalam menyediakan bahan baku yang dibutuhkan mulai dari kebutuhan budidaya, pengemasan sampai kebutuhan kantor. Bahan baku untuk budidaya meliputi benih, pupuk, pestisida, dan peralatan pertanian untuk petani mitra. Bahan baku untuk pengemasan yang dibutuhkan yaitu bahan pengemasan seperti: wrafing film, fresh vegetable tape, dan label.

Pada penelitian Yolandika (2016) diketahui aliran komoditas brokoli dimulai dari petani sebagai petani mitra CV. Yan's Fruits and Vegetable. Semua hasil panen yang memenuhi standar dan kriteria akan ditampung oleh CV. Yan's Fruits and Vegetable. Apabila target produksi yang telah ditetapkan oleh perusahaan tidak dipenuhi oleh petani, maka perusahaan membeli brokoli dari penampung (bandar). Aliran finansial pada rantai pasok brokoli terjadi dari ritel, CV. Yan's Fruits and Vegetable, dan petani. Ritel membayar secara tunai kepada perusahaan yang dibayarkan setelah dua minggu komoditas tersebut dikirimkan. Pembayaran CV. Yan's Fruits and Vegetable kepada petani dilakukan setelah CV. Yan's Fruits and Vegetable menerima pembayaran dari ritel. Sistem komunikasi sudah terintegrasi antara anggota primer dalam rantai pasok. Aliran informasi terjadi pada ritel, perusahaan dan petani atau sebaliknya. Informasi dari perusahaan ke petani berhubungan dengan kapasitas perusahaan, status pengiriman dan berapa pesanan komoditas brokoli yang harus dikirim ke ritel.

Pada rantai pasok brokoli hanya terdapat tiga siklus, yaitu procurement, replenishment, dan customer order. Siklus manufacturing tidak terdapat dalam rantai pasok ini karena tidak

JoFSA Vol. 1, No. 1, April 2017: 30-37 
melibatkan anggota rantai pasok yang berperan sebagai pengolah langsung. Petani mitra hanya melakukan sortasi dan grading, begitu pula dengan CV. Yan's Fruits and Vegetable yang hanya melakukan pengemasan dan pelabelan. Siklus procurement dilakukan oleh ritel kepada CV. Yan's Fruits and Vegetable dan CV. Yan's Fruits and Vegetable kepada petani mitra untuk merespon permintaan konsumen. Pemesanan (pre-order) dilakukan melalui e-mail, pesan singkat, dan faximile. Siklus procurement termasuk dalam proses pull. Siklus replenishment dilakukan oleh ritel dan CV. Yan's Fruits and Vegetable dengan menambah jumlah pesanan dari jumlah pesanan sebenarnya, sebagai antisipasi jika terjadi pemesanan tambahan dari konsumen atau jika terjadi kerusakan pada produk. Siklus replenishment termasuk dalam proses push. Dan siklus customer order dilakukan oleh konsumen dengan memesan secara langsung kepada pihak ritel.

Risiko yang diterima oleh CV. Yan's Fruits and Vegetable lebih banyak daripada yang diterima oleh petani. Sistem kemitraan menyebabkan perusahaan berkewajiban membeli semua hasil panen dari petani sesuai dengan harga yang telah disepakati. Kepercayaan antara CV. Yan's Fruits and Vegetable dengan petani mitra brokoli terbentuk karena telah mengenal satu sama lain. Perusahaan mengetahui kemampuan dan komitmen petani mitra brokoli, sementara petani mitra percaya perusahaan mampu memasarkan brokoli yang dihasilkannya dan mampu menjaga komitmen harga dengan petani. Kepercayaan antara CV. Yan's Fruits and Vegetable dengan pihak ritel terjalin karena CV. Yan's Fruits and Vegetable mampu memenuhi permintaan brokoli secara berkelanjutan dan selalu menjaga kualitas dari brokoli yang dikirim.

Sumber daya fisik pada rantai pasok brokoli meliputi, lahan pertanian di dataran tinggi, kondisi jalan transportasi, sarana dan prasarana pengangkutan. Sumber daya fisik lainnya adalah peralatan yang digunakan dalam budidaya brokoli, seperti cangkul, pacul, arit, plastik mulsa, dan sprayer atau tabung penyemprotan. Untuk penanganan pasca panen brokoli, petani mitra menggunakan pisau stainless steel untuk memotong batang dan daun, keranjang, dan plastik. Petani menggunakan motor untuk mendistribusikan sayuran ke gudang pengemasan CV. Yan's fruits and Vegetable. Sumber daya fisik yang perlu mendapat perhatian adalah kondisi jalan transportasi. Sumber daya manusia yang digunakan di gudang pemasaran sebanyak lima orang pegawai dengan gaji bulanan, 30 orang pegawai harian tetap, termasuk supir.

Teknologi yang digunakan oleh petani mitra pemasok brokoli sudah tepat guna, tetapi masih sederhana. Teknologi yang sederhana juga masih diterapkan di CV. Yan's fruits and Vegetable. Hal ini dikarenakan sayuran yang dikirimkan oelh petani langsun dikemas dan dikirimkan kepada ritel tanpa penundaan. Untuk menjaga kesegaran sayuran selama pengiriman, perusahaan sudah mengandalkan cooler storage. Dalam proses pengemasan brokoli, CV. Yan's fruits and Vegetable telah menggunakan teknologi modern, yaitu plastik wrapping film. Plastik tersebut termasuk dalam kategori teknologi modern karena mempermudah tenaga kerja dalam mengemas brokoli. Selain itu, penggunaan plastik roll film dapat menjaga kualitas brokoli lebih tahan lama.

Petani mitra bertindak sebagai produsen yang bertugas untuk membudidayakan brokoli. CV. Yan's Fruits and Vegetable membeli hasil panen brokoli dari petani mitra, perusahaan melakukan proses sortasi, grading, pengemasan, pelabelan, serta pengiriman brokoli kepada ritel. Struktur organisasi CV. Yan's Fruits and Vegetable sudah mempunyai suatu divisi khusus yang menangani masalah distribusi, sehingga masalah distribusi dapat diatasi dengan baik. Selain itu, CV. Yan's Fruits and Vegetable juga sudah memiliki divisi khusus dalam hal pengadaan bahan baku sayur dan non sayur secara khusus, sehingga proses pengadaan sudah berjalan dengan baik.

Petani brokoli tidak memiliki kriteria khusus pemilihan mitra untuk memasarkan hasil panennya. Petani mitra mengandalkan kepercayaan terhadap CV. Yan's Fruits and Vegetable. Kepercayaan muncul karena adanya saling membutuhkan dan menguntungkan di antara kedua belah pihak. Keuntungan yang didapat petani mitra setelah bergabung dengan CV. Yan's Fruits and Vegetable adalah harga jual yang stabil, posisi tawar dapat meningkat dibandingkan dengan memasarkan sendiri produknya ke pasar tradisional, dan perusahaan mampu membayar secara tunai dan tepat waktu sesuai dengan waktu yang telah disepakati. CV. Yan's Fruits and

Analisis Nilai Tambah Brokoli Kemasan CV. Yans's Fruits and Vegetable (Clara Yolandika) 
Vegetable juga memiliki kriteria dalam memilih mitra pemasar atau ritel yaitu penentuan harga brokoli yang menguntungkan, transparansi informasi pasar, komitmen kerjasama dalam jangka waktu yang lama, dan birokrasi tidak berbelit-belit.

\section{Analisis Nilai Tambah Brokoli Kemasan}

Analisis nilai tambah dilakukan pada komoditas brokoli yang dikemas dalam plastik roll film dan fresh vegetable tape dengan label penjualan. Pada Tabel 2 dapat dilihat hasil analisis nilai tambah pada brokoli kemasan.

Tabel 2 Hasil analisis nilai tambah brokoli dengan Metode Hayami

\begin{tabular}{|c|c|c|}
\hline No & Variabel & Nilai \\
\hline \multicolumn{3}{|c|}{ Output, Input, dan Harga } \\
\hline 1. & Output $(\mathrm{kg})$ & 500 \\
\hline 2. & Bahan Baku (kg) & 500 \\
\hline 3. & Tenaga Kerja Langsung (HOK) & 35 \\
\hline 4. & Faktor Konversi & 1 \\
\hline 5. & Koefisien Tenaga Kerja Langsung (HOK/kg) & 0.07 \\
\hline 6. & Harga Output $(\mathrm{Rp} / \mathrm{kg})$ & 32500 \\
\hline 7. & Upah Tenaga Kerja Langsung (Rp/HOK) & 100000 \\
\hline \multicolumn{3}{|c|}{ Penerimaan dan Keuntungan } \\
\hline 8. & Harga Bahan Baku (Rp/kg) & 20000 \\
\hline 9. & Harga Input lain (Rp/kg) & 500 \\
\hline 10. & Nilai Output $(\mathrm{Rp} / \mathrm{kg})$ & 32500 \\
\hline & a. Nilai Tambah (Rp/kg) & 12000 \\
\hline & b. Rasio Nilai Tambah (\%) & 36.92 \\
\hline \multirow[t]{2}{*}{12.} & a. Pendapatan tenaga kerja Langsung (Rp/kg) & 7000 \\
\hline & b. Pangsa tenaga kerja langsung $(\%)$ & 58.33 \\
\hline \multirow[t]{2}{*}{13.} & a. Keuntungan (Rp/kg) & 5000 \\
\hline & b. Tingkat Keuntungan $(\%)$ & 50000 \\
\hline \multicolumn{3}{|c|}{ Balas Jasa Pemilik Faktor Produksi } \\
\hline & Marjin $(\mathrm{Rp} / \mathrm{kg})$ & 12500 \\
\hline & a. Pendapatan tenaga kerja langsung (\%) & 56 \\
\hline & b. Sumbangan input lain $(\%)$ & 4 \\
\hline & c. Keuntungan perusahaan $(\%)$ & 40 \\
\hline
\end{tabular}

Harga brokoli sebesar Rp 32500 per kilogram merupakan nilai yang diterima oleh perusahaan dari penjualan brokoli. Nilai output merupakan hasil dari perkalian antara faktor konversi dengan harga produk per kilogram. Besarnya nilai produk Rp 32 500, artinya nilai brokoli yang dihasilkan setiap satu kilogram adalah $\mathrm{Rp} 32$ 500. Pengolahan brokoli menghasilkan nilai tambah sebesar Rp 12 000, dengan rasio nilai tambah terhadap nilai produk sebesar 36.92 persen. Artinya untuk setiap Rp 100, nilai output akan memperoleh nilai tambah sebesar 36.92 persen. Penelitian ini sejalan dengan penelitian Setiawan (2011) dimana PT Saung Mirwan memperoleh nilai tambah pada komoditas lettuce head yang dibungkus plastik UV, pada semester 1 sebesar 59.59 persen dan pada semester 2 sebesar 60.41 persen. 


\section{Simpulan dan Saran}

\section{Simpulan}

Kondisi rantai pasok brokoli CV. Yan's Fruits and Vegetable di Kabupaten Bandung Barat sudah memiliki hubungan yang baik pada setiap anggota rantai pasok. Selain itu, pada rantai pasok brokoli telah memiliki sasaran yang jelas, baik sasaran pasar, sasaran pengembangan, dan sasaran produk. Peningkatan kualitas dan pengoptimuman rantai pasok sudah menjadi sasaran setiap pelaku yang terkait dalam rantai pasok brokoli. Sistem komunikasi sudah berjalan dengan baik antara anggota primer dalam rantai pasok. Aliran informasi terjadi pada ritel, perusahaan dan petani atau sebaliknya. Informasi dari perusahaan ke petani berhubungan dengan kapasitas perusahaan, status pengiriman dan berapa pesanan komoditas brokoli yang harus dikirim ke ritel, serta identifikasi komoditas brokoli yang dibutuhkan. Pengintegrasian yang baik inilah yang menyebabkan lancarnya aliran finansial pada rantai pasok brokoli dari ritel, CV. Yan's Fruits and Vegetable, dan petani, sehingga menyebabkan kemitraan dari setiap pelaku rantai pasok selalu berjalan dengan baik. Akan tetapi, masih ada permasalahan pada proses bisnis rantai pasok brokoli, terutama dari sisi perencanaan kolaboratif. Petani mitra brokoli masih memiliki lead time yang panjang, sehingga menyebabkan siklus yang panjang pula untuk memenuhi pesanan. Hal itu menyebabkan tingginya resiko kerusakan brokoli saat proses distribusi.

CV Yan's Fruits and Vegetable memperoleh nilai tambah dari komoditas brokoli. Brokoli yang dikemas menghasilkan nilai tambah sebesar Rp 12 000, dengan rasio nilai tambah terhadap nilai produk sebesar 36.92 persen.

\section{Saran}

Perusahaan diharapkan dapat melakukan perencanaan kolaboratof yang baik dengan petani mitra, dengan cara memberikan informasi kualifikasi order yang jelas, sehingga dapat mengurangi waktu tunggu pemenuhan pesanan dan siklus pemenuhan pesanan melalui perencanaan yang matang. Jika petani sudah memiliki perencanaan yang matang perihal hasil produksinya, maka petani tidak akan membutuhkan waktu yang lama untuk memenuhi kebutuhan brokoli.

Bagi petani mitra, untuk mencapai kinerja rantai pasok yang efisien, maka perlu dilakukan perbaikan dalam kinerja rantai pasok. Perbaikan dapat dilakukan melalui pegurangan biaya total rantai pasok dengan cara mengurangi lead time dan siklus dalam pemenuhan pesanan, sehingga tidak memerlukan tambahan biaya untuk cooler storage dan pengemasan, demi mengurangi resiko kerusakan.

Terkait penelitian lanjutan, diharapkan penelitian mengenai sistem kinerja rantai pasok brokoli dengan menggunakan indikator yang spesifik untuk produk primer, sehingga dapat memperoleh hasil yang lebih akurat.

\section{Ucapan Terima Kasih}

Penulis mengucapkan terima kasih kepada Kementerian Pendidikan dan Kebudayaan Republik Indonesia yang telah memberikan dukungan finansial, sehingga penulis dapat menyelesaikan penelitian ini.

\section{Daftar Pustaka}

[BPS] Badan Pusat Statistik. 2015. Luas Panen dan Produksi Sayuran Indonesia. Badan Pusat Statistik. Jakarta. 
Firmana F. 2016. Analisis Efisiensi Teknis Usahatani Padi di Kabupaten Karawang. Tesis. Institut Pertanian Bogor. Bogor.

Liang, L., Yang, F., Cook, W., D., Zhu, J. 2006. DEA Models for Supply Chain Efficiency Evaluation. Ann Oper Res. 145(1):35-49.

Manning, L., Baines, R., Chadd, S. 2008. Benchmarking the Poultry Meat Supply Chain. Benchmarking: An International Journal. 15(2):148-165.

Pujawan, I., N. 2005. Supply Chain Management. Guna Wijaya. Surabaya.

Purba YO. 2015. Analisis Rantai Pasok Kubis di Kabupaten Simalungun Sumatera Utara. Tesis. Institut Pertanian Bogor. Bogor.

Saragih, A., E. 2016. Analisis Rantai Pasok Berasi di Kecamatan Cibeber Kabupaten Cianjur. Tesis. Institut Pertanian Bogor. Bogor.

Sari, S., W., Nurmalina R, Setiawan B. 2014. Efisiensi Rantai Pasokan Ikan Lele di Indramayu Jawa Barat. Jurnal Manajemen dan Agribisnis. 11(1): 12 - 23.

Sari, P., N. 2012. Analisis Network Supply Chain dan Pengendalian Persediaan Beras Organik (Studi Kasus: Rantai Pasok Tani Sejahtera Farm, Kab Bogor). Tesis. Institut Pertanian Bogor. Bogor.

Setiawan, A., Marimin, Arkeman, Y., Udin, F. 2011. Studi Peningkatan Kinerja Manajemen Rantai Pasok Sayuran Dataran Tinggi di Jawa Barat. Agritech. 31(1): 60-70.

Suwarto A. 2010. Sehat dan Bugar Secara Alami. Niaga Swadaya. Jakarta.

Van der Vorst JUGAJ. 2006. Quantifying the Agri-Food Supply Chain. Logistics and Operations Research Group, Wageningen University. Amsterdam.

Yolandika, C., Nurmalina, R., Suharno. 2016. Supply Chain Management Brokoli di Kecamatan Lembang Kabupaten Bandung Barat. Jurnal Pertanian Terapan. 16(03).

Zulkarnain. 2009. Dasar-Dasar Hortikultura. Bumi Aksara. Jakarta. 